\title{
The Effect of Ear Acupuncture in Reducing Body Weight in Obesity Patients: A Meta-Analysis
}

\author{
Utami Pangestu'), Yulia Lanti Retno Dewi'), Hanung Prasetya3) \\ ${ }^{1)}$ Masters Program in Public Health, Universitas Sebelas Maret \\ 2)Faculty of Medicine, Universitas Sebelas Maret \\ 3)Study Program of Acupuncture, Health Polytechnics, Ministry of Health Surakarta
}

\section{ABSTRACT}

Background: Obesity is now no longer considered a health problem in developed countries, but has also been faced by developing countries such as Indonesia. According to WHO, obesity worldwide has increased by more than two times from 1980. In 2016, there were 1.9 billion adults who were overweight and more than 600 million of them were obese or overweight. This study aims to analyze the effect of ear acupuncture therapy on weight loss.

Subjects and Method: This study was a systematic review and meta-analysis using the Randomized Controlled Trial design. The articles used in this study were obtained from several databases including PubMed, Google Scholar, Springerlink, Hindawi, and Sciencedirect. The articles used in this study were those published from 2008-2020. The article search was carried out by considering the eligibility criteria defined using the PICO model. P: obese patients (BMI $\geq 25)$, I: ear acupuncture therapy, C: no ear acupuncture therapy O: weight loss. The keywords for searching articles are as follows: "auricular acupuncture", AND "obesity", "auricular acupuncture for obesity" and "acupuncture obesity randomized controlled trial". The articles included in this study are full text articles with a Randomized Controlled Trial. Articles were collected using PRISMA flow diagrams. Articles were analyzed using the Review Manager 5.3 application.

Results: A total of 7 articles were reviewed in this study. The meta-analysis showed the results that ear acupuncture therapy was effective for weight loss in obese people $(\mathrm{SMD}=$ $0.74 ; 95 \% \mathrm{CI}=-1.31$ to-0.16; $\mathrm{p}<0.001)$. This meta-analysis combined primary research from Korea, Taiwan and Iran.

Conclusion: Ear acupuncture therapy affects weight loss in obese people.

Keywords: auricular acupuncture, obesity, randomized controlled trial

\section{Correspondence:}

Utami Pangestu. Masters Program in Public Health, Universitas Sebelas Maret, Jl. Ir. Sutami 36A, Surakarta 57126, Central Java. Email: utamipangestu@gmail.com

Cite this as:

Utami Pangestu U, Dewi YLR, Prasetya H (2021). The Effect of Ear Acupuncture in Reducing Body Weight in Obesity Patients: A Meta-Analysis. Indones J Med. 06(01): 23-31. https://doi.org/10.26911/theijmed.2021.06.01.03.

(c) (i) (2) Indonesian Journal of Medicine is licensed under a Creative Commons Attribution-NonCommercial-ShareAlike 4.o International License.

\section{BACKGROUND}

Obesity is now no longer considered a health problem in developed countries, but has also been faced by developing countries such as Indonesia. The lifestyle of residents of developing countries is trying to appear to resemble the lifestyle of developed countries, but they are not only users of technological products but also imitate the unhealthy lifestyles of developed countries. The effects range from poor eating habits to physical inactivity. Broadly speaking, obesity is an imbalance impact of energy intake that far exceeds energy expenditure in a 
certain period of time. Factors that contribute to being overweight include eating too much and lack of moving (Arisman, 2011).

Obesity can be a serious problem when it causes various diseases, such as diabetes mellitus, high blood pressure, high cholesterol, stroke, coronary heart disease, kidney disorders, and several types of cancer (Alexandre et al., 2014). Someone who is obese should lose his/her weight immediately to reduce the risk factors for the disease. Obesity is a pathological condition, in which there is excessive accumulation of fat than is necessary for normal body functions and can interfere with health (WHO, 2016).

According to data from WHO, obesity worldwide has increased by more than two times from 1980. In 2016, there were 1.9 billion adults who were overweight and more than 600 million of them were obese or overweight (WHO, 2016). In western countries, the prevalence of obesity is very high, which is one in three people experiencing it. In Indonesia, obesity has reached $1.5 \%-5 \%$, while overweight has reached $12.8 \%-30 \%$ with a tendency to be two times greater in women than in men. In 2007, the national prevalence of general obesity aged $\geq 15$ years old was $10.3 \%$ (male $13.9 \%$, female $23.8 \%$ ) (Department of Health, 2017).

Ear acupuncture is one of the most practical and long-lasting treatment options with very minimal pain. In a study on the effect of ear acupuncture therapy on obese women conducted by Set et al., (2014), it was shown that after ear acupuncture therapy for 3 months, there was a change in the average value of BMI, and in the study of Yeo et al., (2014) entitled Randomized Clinical Trial of three Ear Acupuncture Points for Treatment of Overweight, after 8 weeks of acupuncture therapy showed a significant decrease in BMI in group I who received ear acupuncture therapy compared to group II who did not receive earacupuncture therapy.

\section{SUBJECTS AND METHOD}

\section{Study Design}

This was a systematic review and meta-analysis study. The articles used in this study were obtained from several databases including PubMed, Google Scholar, Springerlink, Hindawi and Scienceirect. The keywords for finding articles are as follows: "auricular acupuncture", AND "obesity", "auricular acupuncture for obesity" dan "acupuncture obesity randomized controlled trial".

\section{Inclusion Criteria}

The articles included in this study were full paper articles with a Randomized Controlled Trial (RCT) and the articles were in English. The appropriate article should mention a population of obese patients with a BMI of 25, intervention ear acupuncture therapy, comparison of no ear acupuncture therapy with weight loss outcomes. Articles must be published between 2008-2020.

\section{Exclusion Criteria}

The articles published in this study were articles that did not use the subjects of obese patients with $\mathrm{BMI} \geq \mathbf{2 5}$, articles were not in English. The article did not list the standard deviation (SD).

\section{Operational Definition of Variables}

The article search was carried out by considering the eligibility criteria defined using the PICO model. The population in the study were obese patients with BMI $\geq 25$ with intervention in the form of ear acupuncture therapy, comparison which is no ear acupuncture therapy and the outcome in the form of weight loss.

Ear acupuncture therapy is an ear acupuncture therapy technique on specific acupuncture points in the ear. 
Obesity is a condition where there is excessive accumulation of body fat which can interfere with health.

Body weight is the size of the body in terms of weight which is weighed in a state of minimal clothing without any equipment.

\section{Data Analysis}

Data processing was carried out by the Review Manager (RevMan 5.3) by calculating the effect size and heterogeneity to determine which study models were combined and formed the final metaanalysis result.

\section{RESULTS}

The process of searching for articles by searching through a database with journals can be seen in Figure 1. Figure 2 shows the areas where articles were taken according to the inclusion criteria. The articles obtained consist of 7 articles from Korea, Taiwan, Taipei and Iran.

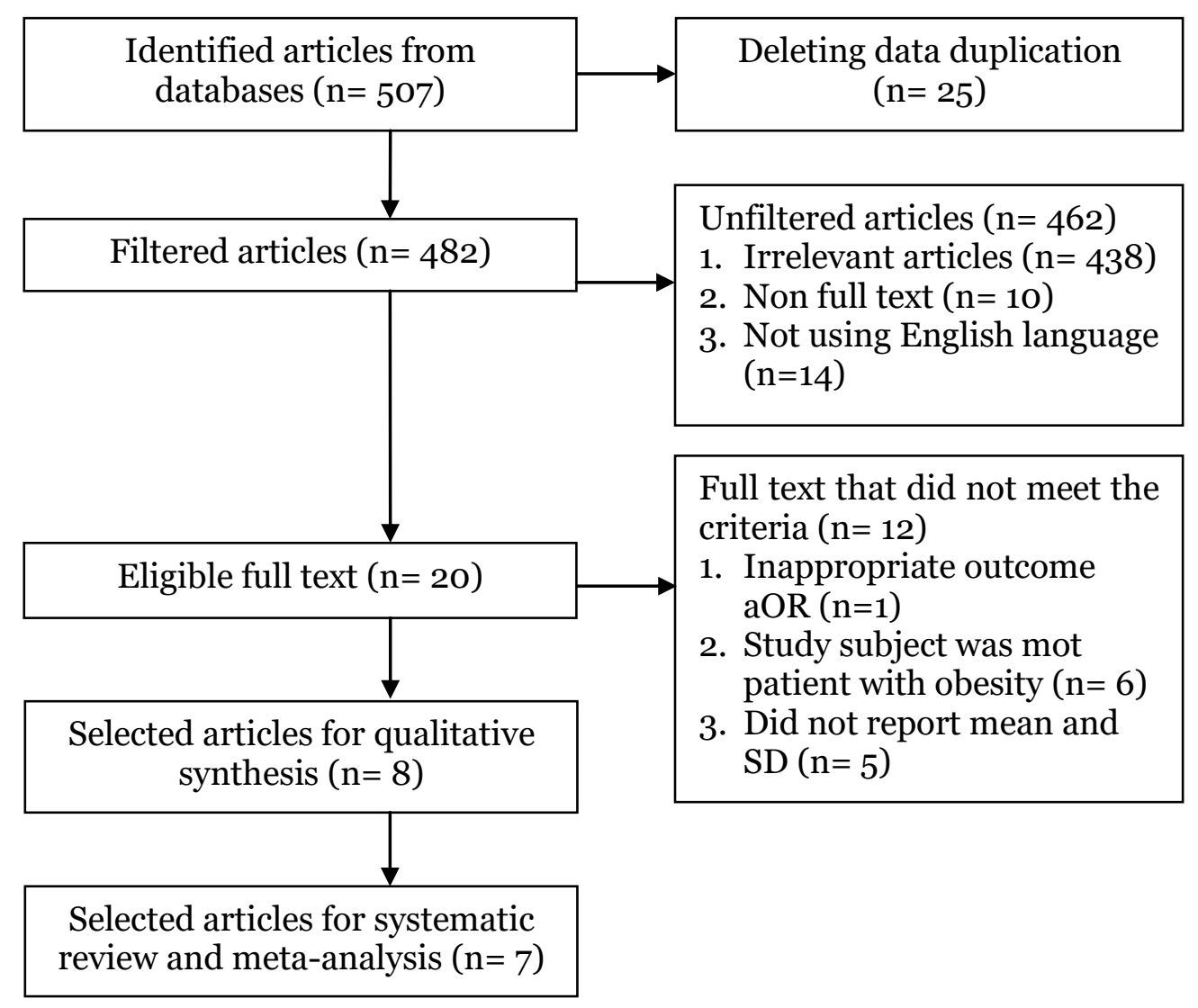

Figure 1. PRISMA flow diagram

Figure 2 shows the areas where articles were obtained according to the inclusion criteria. 7 articles from the Asian continent consisting of Korea, Taiwan, Taipei and Iran. 
Pangestu et al./ Effect of Ear Acupuncture in Reducing Body Weight

\section{Forest Plot}

\begin{tabular}{|c|c|c|c|c|c|c|c|c|c|}
\hline \multirow[b]{2}{*}{ Study or Subgroup } & \multicolumn{3}{|c|}{ Auricular Acupuncture } & \multicolumn{3}{|c|}{ No Auricular Acupuncture } & \multicolumn{2}{|r|}{ Std. Mean Difference } & \multirow{2}{*}{$\begin{array}{l}\text { Std. Mean Difference } \\
\text { IV, Random, } 95 \% \mathrm{Cl}\end{array}$} \\
\hline & Mean & SD & Total & Mean & SD & Total & Weight & IV, Random, $95 \% \mathrm{Cl}$ & \\
\hline Abdi 2012 & 33 & 2 & 37 & 3.7 & 2 & 37 & $14.1 \%$ & $-0.20[-0.65,0.26]$ & $\rightarrow+$ \\
\hline Cha 2019 & 5 & 4.6 & 86 & 5 & 4.6 & 89 & $14.8 \%$ & $0.00[-0.30,0.30]$ & $\rightarrow$ \\
\hline Hsieh 2011 & 3.41 & 1.38 & 60 & 5.35 & 1.8 & 60 & $14.4 \%$ & $-1.20[-1.59,-0.81]$ & - \\
\hline Hsu 2009 & 2.93 & 0.41 & 44 & 4.3 & 0.71 & 36 & $13.3 \%$ & $-2.40[-2.99,-1.82]$ & $\longrightarrow$ \\
\hline Kim 2014 & 2.49 & 0.67 & 41 & 3.67 & 0.95 & 43 & $13.9 \%$ & $-1.42[-1.90,-0.94]$ & $\longrightarrow$ \\
\hline Yeh 2008 & 2.7 & 1.1 & 80 & 2.7 & 1.1 & 79 & $14.8 \%$ & $0.00[-0.31,0.31]$ & \\
\hline Yeo 2013 & 1.41 & 0.85 & 78 & 1.52 & 0.89 & 70 & $14.7 \%$ & $-0.13[-0.45,0.20]$ & $-\pi$ \\
\hline Total $(95 \% \mathrm{Cl})$ & & & 426 & & & 414 & $100.0 \%$ & $-0.74[-1.31,-0.16]$ & \\
\hline \multicolumn{5}{|c|}{ Test for owerall effect: $Z=2.51(P=0.001)$} & & & & & $\begin{array}{cccc}-2 & -1 & 0 & 1 \\
\text { Auricular Acupuncture } & \text { No Auricul }\end{array}$ \\
\hline
\end{tabular}

\section{Figure 3. Forest Plot on the effect of ear acupuncture therapy on weight loss}

Based on the results of the forest plot (Figure 3), ear acupuncture therapy was able to reduce body weight by -0.74 units compared to no ear acupuncture therapy which was statistically significant ( $\mathrm{p}<0.001)$. The heterogeneity of the study data shows I2 $=94 \%$ so that the data is heterogeneous (random effect model).

\section{Funnel Plot}

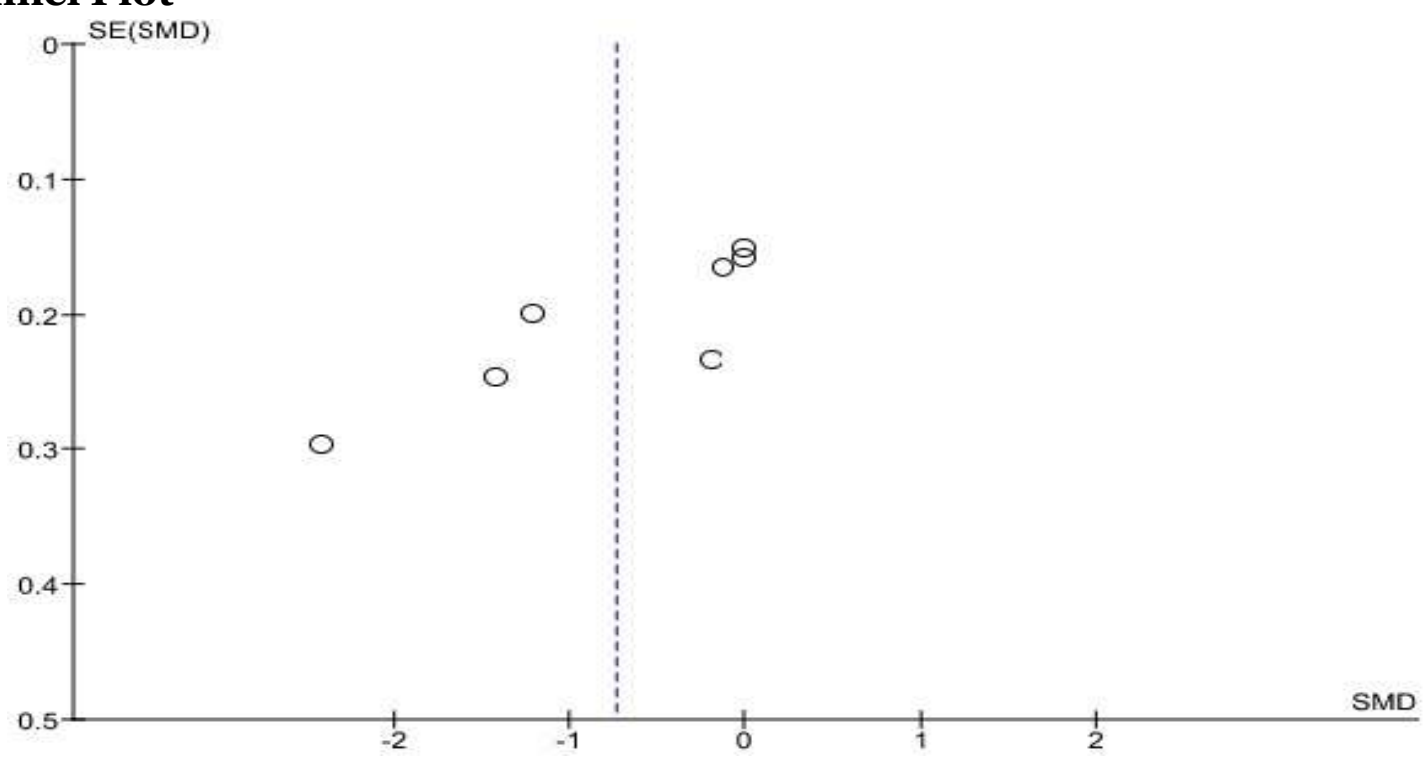

Figure 4. Funnel Plot on the effect of ear acupuncture therapy on weight loss

Funnel plot (Figure 4) showed the effect of ear acupuncture therapy on weight loss shows that there was no publication bias which was indicated by the symmetrical plot on the right and left where 4 plots are on the right and 3 plots are on the left. 
Summary Source

Table 1. Primary study descriptions included in the meta-analysis

\begin{tabular}{|c|c|c|c|c|c|c|c|}
\hline $\begin{array}{l}\text { Author } \\
\text { (Year) }\end{array}$ & Country & $\begin{array}{l}\text { Study } \\
\text { Design }\end{array}$ & Sample & $\mathbf{P}$ & I & $\mathbf{C}$ & $\mathbf{O}$ \\
\hline $\begin{array}{l}\text { Cha et } \\
\text { al.,(2019) }\end{array}$ & Korea & $\begin{array}{l}\text { Randomized } \\
\text { Controlled } \\
\text { Trial }\end{array}$ & $\begin{array}{l}\text { Ear acupuncture: } \\
86 \\
\text { No ear } \\
\text { acupuncture: } 89\end{array}$ & $\begin{array}{l}\text { Obese people } \\
\text { aged 18-24 years } \\
\text { old }\end{array}$ & $\begin{array}{l}\text { This study aims to determine } \\
\text { the effect of ear point } \\
\text { acupuncture on weight loss } \\
\text { in adolescents. }\end{array}$ & $\begin{array}{l}\text { Not to know the effect of ear } \\
\text { point acupuncture on weight } \\
\text { loss in adolescents. }\end{array}$ & $\begin{array}{l}\text { Weight } \\
\text { loss }\end{array}$ \\
\hline $\begin{array}{l}\text { Abdi et } \\
\text { al.,(2012) }\end{array}$ & Iran & $\begin{array}{l}\text { Randomized } \\
\text { Controlled } \\
\text { Trial }\end{array}$ & $\begin{array}{l}\text { Ear acupuncture: } \\
37 \\
\text { No ear } \\
\text { acupuncture: } 37\end{array}$ & $\begin{array}{l}\text { Obese people } \\
\text { aged 18-55 years } \\
\text { old }\end{array}$ & $\begin{array}{l}\text { Checking the effectiveness of } \\
\text { auricular acupuncture on } \\
\text { weight loss }\end{array}$ & $\begin{array}{l}\text { Not to examine the effectiveness } \\
\text { of auricular acupunctur against } \\
\text { weight loss }\end{array}$ & $\begin{array}{l}\text { Weight } \\
\text { loss }\end{array}$ \\
\hline $\begin{array}{l}\text { Hsieh et } \\
\text { al.,(2011) }\end{array}$ & Taiwan & $\begin{array}{l}\text { Randomized } \\
\text { Controlled } \\
\text { Trial }\end{array}$ & $\begin{array}{l}\text { Ear acupuncture: } \\
60 \\
\text { No ear } \\
\text { acupuncture: } 60\end{array}$ & $\begin{array}{l}\text { Obese people } \\
\text { aged 18-20 years } \\
\text { old }\end{array}$ & $\begin{array}{l}\text { Test the efficiency of ear } \\
\text { acupuncture on * weight loss } \\
\text { \& changes in waist } \\
\text { circumference. }\end{array}$ & $\begin{array}{l}\text { Not to test the efficiency of ear } \\
\text { acupuncture on }{ }^{*} \text { weight loss \& } \\
\text { waist circumference changes. }\end{array}$ & $\begin{array}{l}\text { Weight } \\
\text { loss }\end{array}$ \\
\hline $\begin{array}{l}\text { Kim et } \\
\text { al.,(2014) }\end{array}$ & Korea & $\begin{array}{l}\text { Randomized } \\
\text { Controlled } \\
\text { Trial }\end{array}$ & $\begin{array}{l}\text { Ear acupuncture: } \\
41 \\
\text { No ear } \\
\text { acupuncture: } 43\end{array}$ & $\begin{array}{l}\text { Obese people } \\
\text { aged } 20-40 \text { years } \\
\text { old }\end{array}$ & $\begin{array}{l}\text { Knowing the effects of ear } \\
\text { point acupuncture with } \\
\text { S.alba on *obesity and self- } \\
\text { efficacy. }\end{array}$ & $\begin{array}{l}\text { Not to know the effect of ear } \\
\text { point acupuncture with S.alba } \\
\text { on obesity }{ }^{*} \text { and self-efficacy. }\end{array}$ & $\begin{array}{l}\text { Weight } \\
\text { loss }\end{array}$ \\
\hline $\begin{array}{l}\text { Yeh et } \\
\text { al., } \\
(2008)\end{array}$ & Taiwan & $\begin{array}{l}\text { Randomized } \\
\text { Controlled } \\
\text { Trial }\end{array}$ & $\begin{array}{l}\text { Ear acupuncture: } \\
80 \\
\text { No ear } \\
\text { acupuncture: } 79\end{array}$ & $\begin{array}{l}\text { Obese people } \\
\text { aged 22-50 years } \\
\text { old }\end{array}$ & $\begin{array}{l}\text { Test the effectiveness of } \\
\text { acupuncture on ear points } \\
\text { for obesity cases. }\end{array}$ & $\begin{array}{l}\text { Did not test the effectiveness of } \\
\text { ear point acupuncture for } \\
\text { obesity. }\end{array}$ & $\begin{array}{l}\text { Weight } \\
\text { loss }\end{array}$ \\
\hline $\begin{array}{l}\text { Yeo et } \\
\text { al., } \\
(2013)\end{array}$ & Korea & $\begin{array}{l}\text { Randomized } \\
\text { Controlled } \\
\text { Trial }\end{array}$ & $\begin{array}{l}\text { Ear acupuncture: } \\
78 \\
\text { No ear } \\
\text { acupuncture: } 70\end{array}$ & $\begin{array}{l}\text { Obese people } \\
\text { aged }>19 \text { years } \\
\text { old }\end{array}$ & $\begin{array}{l}\text { Evaluating the effect of ear } \\
\text { acupuncture points on } \\
\text { weight loss in obese people. }\end{array}$ & $\begin{array}{l}\text { Not to evaluate the effect of ear } \\
\text { acupuncture points on weight } \\
\text { loss in obese people. }\end{array}$ & $\begin{array}{l}\text { Weight } \\
\text { loss }\end{array}$ \\
\hline $\begin{array}{l}\text { Hsu et } \\
\text { al., } \\
\text { (2009) }\end{array}$ & Taiwan & $\begin{array}{l}\text { Randomized } \\
\text { Controlled } \\
\text { Trial }\end{array}$ & $\begin{array}{l}\text { Ear acupuncture: } \\
44 \\
\text { No ear } \\
\text { acupuncture: } 36\end{array}$ & $\begin{array}{l}\text { Obese people } \\
\text { aged 16-65 years } \\
\text { old }\end{array}$ & $\begin{array}{l}\text { Examining the effect of ear } \\
\text { acupuncture in obese women } \\
\& \text { the relationship between } \\
\text { ear acupuncture's effect on } \\
\text { obesity-related weight loss. }\end{array}$ & $\begin{array}{l}\text { Did not examine the effect of } \\
\text { ear acupuncture in obese } \\
\text { women \& the relationship } \\
\text { between ear acupuncture's } \\
\text { effect on obesity-related weight } \\
\text { loss. }\end{array}$ & $\begin{array}{l}\text { Weight } \\
\text { loss }\end{array}$ \\
\hline
\end{tabular}


Table2. Critical Appraisal Checklist

\begin{tabular}{|c|c|c|c|c|c|c|c|}
\hline Checklist Questions & $\begin{array}{l}\text { Cha et al. } \\
\text { (2019) }\end{array}$ & $\begin{array}{l}\text { Abdi et al. } \\
\text { (2012) }\end{array}$ & $\begin{array}{c}\text { Hsieh } \\
\text { et al. } \\
\text { (2011) } \\
\end{array}$ & $\underset{(2014)}{\text { Kim et al. }}$ & $\begin{array}{l}\text { Yeh et al. } \\
(2008)\end{array}$ & $\begin{array}{c}\text { Yeo et } \\
\text { al. } \\
(2013)\end{array}$ & $\begin{array}{c}\text { Hsu et } \\
\text { al. } \\
(2009)\end{array}$ \\
\hline $\begin{array}{l}\text { Does this objective clearly address the focus/study } \\
\text { problem? }\end{array}$ & 1 & 1 & 1 & 1 & 1 & 1 & 1 \\
\hline $\begin{array}{l}\text { Is the study method (study design) appropriate for } \\
\text { answering study questions? }\end{array}$ & 1 & 1 & 1 & 1 & 1 & 1 & 1 \\
\hline $\begin{array}{l}\text { Is the method of selecting study subjects clearly } \\
\text { written? }\end{array}$ & 1 & 1 & 1 & 1 & 1 & 1 & 1 \\
\hline Can the sampling method introduce bias (selection)? & o & o & o & o & o & o & o \\
\hline $\begin{array}{l}\text { Does the study sample taken represent the } \\
\text { designated population? }\end{array}$ & 1 & 1 & 1 & 1 & 1 & 1 & 1 \\
\hline $\begin{array}{l}\text { Is the sample size based on pre-study } \\
\text { considerations? }\end{array}$ & o & 1 & o & o & o & o & 1 \\
\hline Is a satisfactory response achieved? & 1 & 1 & 1 & 1 & 1 & 1 & 1 \\
\hline Are the research instruments valid and reliable? & 1 & 1 & 1 & 1 & 1 & 1 & 1 \\
\hline Is statistical significance assessed? & 1 & 1 & 1 & 1 & 1 & 1 & 1 \\
\hline Are confidence intervals given for the main outcome? & 1 & 1 & 1 & 1 & 1 & 1 & 1 \\
\hline $\begin{array}{l}\text { Are there any confounding factors that haven't been } \\
\text { taken into account? }\end{array}$ & o & o & o & o & o & o & o \\
\hline Are the results applicable to your study? & 1 & 1 & 1 & 1 & 1 & 1 & 1 \\
\hline $\begin{array}{c}\text { Total } \\
\end{array}$ & 9 & 10 & 9 & 9 & 9 & 9 & 10 \\
\hline
\end{tabular}

Information: Yes $=1$, No $=0$ 


\section{DISCUSSION}

This systematic review and meta-analysis study raised the theme of the effect of ear acupuncture therapy on weight loss in obese patients. This study discussed data about ear acupuncture considered important because of its rarity and effectiveness. The number of relevant research published and accessible is still small and also has data access problems (data duplication) (Murti, 2018).

Confounding factors affect the relationship or effect of exposure to the occurrence of disease estimated (estimated) by the study is not the same as the relationship or effect that actually occurs in the target population, which can be stated as invalid (incorrect) study results (Murti, 2018). This systematic study and meta-analysis study used studies that has controlled for confounding factors which can be seen from the study inclusion requirements, namely standardized mean differences.

Estimates of the combined effect of ear acupuncture therapy were processed by using RevMan 5.3 with the Continous method. This method was used to analyze the effect size or standardized mean difference in the bivariate data of two groups that had been controlled for confounding factors by randomization.

A funnel plot is a diagram in a metaanalysis used to demonstrate possible publication bias. The funnel plot shows the relationship between the effect size of the study and the sample size or standard error of the effect size of the various studies studied (Murti, 2018). The funnel plot shows visually the amount of variation (heterogeneity) (Akobeng, 2005 in Murti, 2018).

The funnel plot shows the relationship between the effect size of the study and the sample size of the various studies under study, which can be measured in a number of different ways (Murti, 2018).

Systematic review and meta-analysis in this study were carried out with the aim of increasing the generalizability of the findings and obtaining convincing conclusions from the results of various similar studies regarding ear acupuncture therapy in losing weight in obese patients.

Hsieh et al., (2011) stated that ear acupuncture therapy is effective against weight loss and changes in waist circumference in 60 respondents who are obese compared to 60 obese respondents in the control group who do not show any significant results. Thus acupuncture at the ear point can be an effective therapy for weight loss programs.

These results were supported by Kim et al., (2014) which stated that acupuncture at the ear point is effective for weight loss in obese patients and is safer than using other methods, in addition, ear acupuncture is also effective for increasing self-efficacy in obesity sufferers.

This meta-analysis concluded that ear acupuncture therapy is effective for weight loss in obese patients, ear acupuncture therapy is able to lose weight in obese patients by -0.74 units greater than no ear acupuncture therapy $(\mathrm{SMD}=-0.74 ; 95 \%$ $\mathrm{CI}=-1.31$ to -0.16 ; $\mathrm{p}<0.001)$. This metaanalysis combines 7 primary studies with randomized controlled trials from Korea, Taiwan, Taipei and Iran.

\section{AUTHOR CONTRIBUTION}

Utami is the main researcher who selected topics, tracked and collected the data. Yulia and Hanung have the role in analyzing data and reviewing study documents.

\section{CONFLICT OF INTEREST}

There was no conflict of interest in this study. 
FUNDING AND SPONSORSHIP

This study used personal fund from the main reasearcher.

\section{ACKNOWLEDGEMENT}

We are very grateful to the database providers namely PubMed, Google Scholar and Hindawi.

\section{REFERENCE}

Abdi H, Parized P, Zhao B, Mobarhan M, Tavallaie $S$ (2012). Effects of auricular acupuncture on anthropometric: A randomized controlled trial study. The Journals of alternative and Complementary Medicine 18(7): 668677. DOI: 10.1069/acm.2011.0244.

Alexandre L, Long E, Beales I (2014). Pathophysiological mechanisms linking obesity and esophageal adenocarcinoma. World J Gastrointest Pathophysiol. 5(4): 534-549. https://dx.doi.org/10.4291\%2Fwjgp.v5.i4.534.

Arisman (2011). Diabetes Mellitus. Dalam: Arisman, ed. Buku ajar ilmu gizi obesitas, diabetes mellitus dan dislipidemia (Diabetes mellitus. In: Arisman, ed. Textbook of Nutrition Science of Obesity, Diabetes Mellitus and Dyslipidemia. Jakarta: EGC.

Cha SH, Park H (2019). Effects of auricular acupuncture on obesity in adolescents with obesity. Complementary Therapies in Clinical Practice. (35): 316322. doi: 10.1016/j.ctep.2019.03.014.

Departemen Kementerian Kesehatan RI (2017). Pedoman Proses Asuhan Gizi di Puskesmas (Guidelines for Nutritional Care Process at Community Health Center). Jakarta: Kemenkes RI.

Hsieh CH (2011). Effects of auricular acupuncture on weight reduction and abdominal obesity in Asian young adult: A randomized controlled trial.
The American Journals of Chinese Medicine 39(3): 433-440. DOI:10.1142/So1924415X11008932.

Hsu Chung-Hua, Chou Pesus (2008). The effect of auricular acupuncture in obese woman: A randomized controlled trial. Journal of Woman's Health. 18(6): 813-818. DOI:10.1089/jwh.2008.1005 .

Kim D, Ham KO, Kang C (2014). Effects of auricular acupuncture ussing sinaps alba seeds on obesity and self-efficacy in female collague student. The Journals of alternative and Complementary Medicine. 20(4): 258-264. DOI: $10.1089 / 1 \mathrm{~cm} .2012 .0283$

Murti B (2018). Prinsip dan Metode Riset Epidemiologi (Epidemiological Research Principles and Methods). Edisi V. Program Studi Ilmu Kesehatan Masyarakat, Program Pascasarjana, Universitas Sebelas Maret. Surakarta. Bintang Fajar Offsite Colomadu, Karanganyar.

Purnami I (2015). Prevalensi obesitas dan hubungan antara obesitas dengan kejadian hipertensi dan proteinuria pada anak usia 12-14 tahun di sekolah menengah pertama swasta di Kota Denpasar (Prevalence of obesity and relationship between obesity and incidence of hypertension and proteinuria in children ages 12-14 years in Private Junior High Schools in Denpasar City). Tesis. Program Studi Ilmu Biomedik Program Pascasarjana. Universitas Udayana. Denpasar.

Set T, Cayir Y, Pirim A (2014). Effect of ear acupuncture therapy for obesity on the depression of obese women. Acupunct Med. 32(5): 427-429. https://doi.org/10.1136/acupmed-2014-010626.

WHO (2016). Overweight and obesity fact sheet, [online]. http://www.who.int 
Pangestu et al./ Effect of Ear Acupuncture in Reducing Body Weight

/mediacentre/factsheets/fs311/en/ [diakses September 2020].

WHO (2017). Obesity and Overweight. http://www.who.intt/mediacenter/fa cesheet/fs311/en/. Accessed November 2020.

Yeh CH, Yeh SCJ (2008). Effects of ear points pressing on parameters related on obesity in non-obese healty and obese volunteers. The Journals of alternative and Complementary Medicine 14(3): 309-314. Doi: 10.1089/acm.2007.0678.

Yeo S, Kim KS, Lim S (2014). Randomised clinical trial of ear acupuncture points for the treatment of overweight people. Acupunct Med. 32(2): 132-138. https://doi.org/10.1136/acupmed2013-010435. 